\title{
Bioprospecting wild South African microalgae as a potential third-generation biofuel feedstock, biological carbon-capture agent and for nutraceutical applications
}

\author{
Elvis Kodzo Ahiahonu ${ }^{1,2} \cdot$ William Wilson Anku³ $\cdot$ Ashira Roopnarain ${ }^{4} \cdot$ Ezekiel Green $^{5}$. Penny Poomani Govender ${ }^{1}$. \\ Mahloro Hope Serepa-Dlamini ${ }^{5}$ (D)
}

Received: 23 March 2021 / Revised: 4 June 2021 / Accepted: 18 June 2021

(c) The Author(s) 2021

\begin{abstract}
Microalgae are among the few biological resources studied that are found to possess vast biotechnological potential. This study isolated, identified and investigated two wild green microalgal species with substantial potential as a bioresource and climate change mitigation importance. Two isolates, Chlorella sorokiniana and Tetradesmus reginae were cultivated in selected artificial media under laboratory conditions. The isolates were analysed for nutrient consumption, biomass productivity, $\mathrm{CO}_{2}$ biosequestration rate, elemental composition and fatty acid methyl profiles/composition. The outcome showed maximum daily biomass productivity of $0.128 \pm 0.003$ and $0.2 \pm 0.004 \mathrm{~g} \mathrm{~L}^{-1}$ for $C$. sorokiniana and T. reginae, respectively. $\mathrm{CO}_{2}$ biosequestration rate of $T$. reginae was the highest among the isolates, indicating that it can act as a biological climate change mitigation agent. Moreover, T. reginae recorded a significantly higher $(p<0.05)$ total lipid and carbohydrate content than $C$. sorokiniana. The $\mathrm{C} / \mathrm{N}$ ratio for $T$. reginae was significantly higher than the $\mathrm{C} / \mathrm{N}$ ratio for $C$. sorokiniana. Tetradesmus reginae also demonstrated the ability to produce a considerable quantity of omega-3 oils; hence, the species is of nutraceutical importance. Furthermore, T. reginae demonstrated maximal carbohydrate content and is therefore considered a potential feedstock for bioethanol production. Chlorella sorokiniana, on the other hand, showed a remarkable $(p<0.05)$ protein content making it a potential source for human food and animal feed supplement. Finally, the two isolates met both European and American quality biodiesel standards with exceptional cetane (CN) and iodine numbers (IV).
\end{abstract}

Keywords Algae $\cdot$ Biofuel · Biosequestration - Chlorella sorokiniana $\cdot$ Climate change $\cdot$ Tetradesmus (Acutodesmus) reginae

Mahloro Hope Serepa-Dlamini

hopes@uj.ac.za

1 Department of Chemical Sciences, University of Johannesburg, Doornfontein Campus, P.O. Box 17011, Johannesburg 2028, South Africa

2 Environmental Protection Agency, P.O Box MB 326, Accra, Ghana

3 CSIR-Water Research Institute, P.O. Box M. 32, Accra, Ghana

4 Microbiology and Environmental Biotechnology Research Group, Institute for Soil, Climate and Water-Agricultural Research Council, Private Bag X79, Pretoria 0001, South Africa

5 Department of Biotechnology and Food Technology, University of Johannesburg, Doornfontein Campus, P.O. Box 17011, Johannesburg 2028, South Africa

\section{Introduction}

Microalgae are simple prokaryotic or eukaryotic organisms found in nearly every environment, especially the aquatic ecosystem. Microalgae are essential primary producers in the ecosystem due to their ability to harness solar energy for photosynthesis. Studies have shown that when compared to higher plants, algae have one of the most efficient photosynthetic and biomass productivity rates [1,2], and this results in an elevated biomass build-up. Other studies also reported that most microalgal species have great potential and value as bio-resources and climate mitigation agents $[3,4]$. To determine optimal use for more than 1,000,000 microalgal species, on-going investigations are conducted globally to analyse their primary metabolites (proteins, carbohydrates, lipids, fatty acids, amino acids, vitamins and sterols) and useful secondary metabolites (including allelochemicals, 
toxins and hormones) [5-7]. The economics of microalgal cultivation, where all that is needed is low-cost water and atmospheric $\mathrm{CO}_{2}$, has piqued researchers' interest even more. Moreover, they can grow on non-arable land; hence, the competition for land for food crop cultivation is eliminated. Nevertheless, a nutrient-rich medium is necessary for microalgae cultivation [3].

Recent reports on alarming levels of atmospheric $\mathrm{CO}_{2}$ and resultant climate change-related issues due to combustion of fossil fuel for energy has been a cause for concern among global leaders [8]. For example, 2020 data indicates atmospheric $\mathrm{CO}_{2}$ levels were about $412 \mathrm{ppm}$, almost twice the figure recorded during pre-industrial times [9]. Increasing atmospheric $\mathrm{CO}_{2}$ levels have several negative consequences, including rise in sea level, species extinction, food security risks and threats to ecosystem functioning and biodiversity survival [10]. Therefore, the world is currently in search of a sustainable carbon mitigation technology and carbon-neutral or carbon-negative alternative energy source to fossil fuel, whose source might even be depleted soon. Currently, researchers have identified microalgae-based technologies as having an efficient photosynthesis mechanism capable of effectively biosequestering $\mathrm{CO}_{2}$ from a point source into a biomass that could be considered a potential source of biofuels, a promising but currently expensive alternative to fossil fuels [11-13]. Research data compiled by Sidney et al. [12] on carbon fixation rates by species of microalgae, whilst assessing the role of microalgae technologies in the global carbon market, revealed that genera-Anabaena, Chlorococcum, Spirulina, Chlorella, Botryococcus and Haematococcus have the greatest carbon fixation potential.

Currently, South Africa generates $90 \%$ of its domestic energy from coal resources with deleterious environmental implications, which has called for the intensification of research into sustainable energy development from indigenous renewable resources [14]. Though South Africa is considered semi-arid, its distinguishing geological and geographical features promote biodiversity including algae [15, 16]. This could be an essential lead to exploring more renewable energy options, especially third-generation biofuels, to tackle climate change problems thoroughly, energy deficit and sustainable growth in the country. Moreover, indigenous microalgal species that contain economic quantities of protein and omega oils in their biomass can be harnessed as raw material for the animal feed, human food and food supplement industries.

This study focused on the bioprospecting of native microalgal species that can potentially provide commercially relevant and sustainable raw materials for the biofuel and nutraceuticals industry in the Southern Africa region. Wild microalgae species were obtained from a South African freshwater wetland and assessed for their potential to accumulate carbohydrate and lipids of commercial value.
Thus, the objective of this work was to isolate and identify local wild microalgae using molecular barcoding approach. Furthermore, isolates of interest were cultivated in artificial media for the assessment of its biomass production, nutrient utilisation, elemental and biochemical composition, $\mathrm{CO}_{2}$ biosequestration efficiencies and fatty acid profiles.

\section{Materials and methods}

\subsection{Microalgae sample collection, isolation and unialgal stock culture maintenance}

Algae-rich water samples were collected from a freshwater site with a global positioning system (GPS) coordinates 26.09'04.4"S, 28.03'19.4"E in Killarney Country Club, Johannesburg, Gauteng Province, South Africa, in August 2019. Composite samples from the surface water at depths between 10 and $100 \mathrm{~cm}$ were collected in well-labelled 100 $\mathrm{mL}$ sampling bottles. Sample collection was conducted at prevailing conditions of $20^{\circ} \mathrm{C}$ and $\mathrm{pH} 8.6$ between 10 and 11 am and samples were transported to the laboratory on ice. The field samples were serially diluted and added to sterilised modified Blue-Green 11 (BG-11) medium [17] and Bold's basal medium (BBM) [18] in a ratio of $1: 1(\mathrm{v} / \mathrm{v})$ in $50 \mathrm{~mL}$ conical flasks to promote microalgae growth. Cultures were grown in a Labcon $3081 \mathrm{U}$ shaking incubator (Labcon, South Africa) maintained at a temperature similar to that of the collection site under low light of $1000 \mathrm{~lx}$ and $14 \mathrm{~h} / 10 \mathrm{~h}$ light/dark photoperiod for 10 days.

Modified BG-11 and BBM agar plates were prepared by dissolving $15 \mathrm{~g}$ bactoagar per litre (L) of deionised water in a $2 \mathrm{~L}$ conical flask and autoclaving the resulting solution $\left(121^{\circ} \mathrm{C}\right.$ for $\left.15 \mathrm{~min}\right)$. The molten agar was then mixed at a temperature of $60{ }^{\circ} \mathrm{C}$ with the same volume of either sterilised BG-11 medium or BBM medium slowly whilst swirling to ensure uniform mixing. The mixtures were poured into Petri dishes, allowed to solidify and stored (in an inverted position) at $4{ }^{\circ} \mathrm{C}$ [19]. Mixed microalgal colonies were cultured on sterilised agar-modified BG-11 medium and BBM medium plates, respectively. The plates were incubated at a temperature of $22 \pm 3{ }^{\circ} \mathrm{C}$ with continuous illumination, and single colonies were repeatedly subcultured until unialgal isolates were obtained with the aid of light micrograms at every stage. Eight unialgal colonies were isolated and labelled UJEAS1, UJEAS2, UJEAS3, UJEAS4, UJEAS5, UJEAS6, UJEAS7 and UJEAS8. Colonies of unialgal strains from the agar plates were transferred to $100 \mathrm{~mL}$ conical flasks containing $60 \mathrm{~mL}$ media (either BG-11 or BBM) and cultivated in a Labcon 3081U shaking incubator (Labcon, South Africa) at a speed of $150 \mathrm{rpm}$ for 10 min with a temperature of $25 \pm 3^{\circ} \mathrm{C}, 2000-2500 \mathrm{~lx}$ using Digital Lux Meter AS803 (Arco Science \& Technology Ltd, 
China) lighting condition and 14/10 photoperiod for 8 days to produce the stock cultures meant for morphological and genetic analysis as well as subsequent inoculum.

\subsection{Morphological analysis of microalgae isolates}

The preliminary identity of microalgal isolates were established using morphological methods. Briefly, labelled isolates were viewed under the LEICA DM500 light microscope, and the respective images were captured with a LEICA ICC 50W camera (Leica Microsystems, USA) at $400 \times$ magnification. Culture contamination was regularly checked by comparing the microscopic images with the isolates in the stock cultures. The isolates were further subjected to molecular analysis and identification of the species.

\subsection{Molecular identification and phylogeny}

\subsubsection{Genomic DNA extraction}

Genomic DNA was extracted from the respective unialgal stock cultures with Quick-DNA ${ }^{\text {TM }}$ Plants/Seed DNA MiniPrep Kit (Zymo Research-USA) according to manufacturer's instructions. The extracted DNA was stored at $-20^{\circ} \mathrm{C}$ for further use.

\subsubsection{Polymerase chain reaction and sequencing}

Polymerase chain reaction for each sample was targeted at the nuclear genome, internal transcribed spacer 2 ( ITS2) region $[20,21]$. The primers used to amplify the ITS2 region included forward 5'-AGGAGAAGTCGTAACAAG GT-3' and reverse 5'-TCCTCCGCTTATTGATATGC-3' [22]. Polymerase chain reaction (PCR) was conducted in a BIO-RAD T100 ${ }^{\mathrm{TM}}$ Thermal Cycler (Bio-Rad Laboratories, USA) at an initial denaturation of $95^{\circ} \mathrm{C}$ for 4 min followed by 35 cycles of denaturation at $95^{\circ} \mathrm{C}$ for $2 \mathrm{~min}$, annealing at $55^{\circ} \mathrm{C}$ for $30 \mathrm{~s}$ and extension at $72{ }^{\circ} \mathrm{C}$ for $5 \mathrm{~min}$ and a final extension at $72{ }^{\circ} \mathrm{C}$ for $10 \mathrm{~min}$. The integrity of all PCR products was assessed by viewing the PCR products under UV light on a $1.4 \%$ agarose gel stained with ethidium bromide (EtBr). All PCR products were sequenced by a commercial service provider, Inqaba Biotechnical (Pty) Ltd, Pretoria, South Africa. BioEdit v 7.2 (Informer Technologies, Inc.) was used to analyse the forward and reverse reads and to generate consensus sequences.

\subsubsection{Phylogenetic analysis}

To establish the phylogeny of the isolated microalgae, basic local alignment search tool for nucleotides (BLASTn) was employed to compare ITS 2 sequences of the isolates with the existing National Centre for Biotechnology Information
(NCBI) database sequences to identify closest homologues. Molecular Evolutionary Genetics Analysis version 7.0 (MEGA 7) [23] software was used to perform multiple sequence alignment of related microalgae species from the NCBI database and isolate sequences. The MEGA 7 software was subsequently employed to generate phylogenetic trees using the maximum-likelihood (ML) algorithm with the Tamura-Nei model option [24], and branch reliabilities were evaluated with a bootstrap of 1000 replicate for the identification of the unknown microalgae isolates.

\subsection{Microalgae cultivation and analytical determinations}

Unialgal cultures were batch cultivated in triplicate in BG-11 or BBM growth media under autotrophic growth conditions for 16 days. Parameters such as $\mathrm{pH}$, temperature and residual nitrate-nitrogen (nitrate- $\mathrm{N}$ ) levels in the cultures were monitored every $48 \mathrm{~h}$. Prior to cultivation, unialgal stock cultures were taken during the exponential growth phase, which was at day 8 , centrifuged at the conditions stated at Sect. 2.1 and washed twice with deionised water. The pasty unialgal cells were then reconstituted in deionised water and finally inoculated in $1 \mathrm{~L}$ conical flasks containing either BG-11 or BBM ratio 1:10 (algal cell inoculum: culture nutrient medium). This culminated into an initial culture optical densities of 0.052 and 0.015 for UJEAS4 and UJEAS8, respectively. The cultures were initially sparged with pure $\mathrm{CO}_{2}$ at the flow rate of $1 \mathrm{~L} \mathrm{~min}^{-1}$ for $20 \mathrm{~s}$ and subsequently bubbled with filtered air $\left(0.04 \% \mathrm{CO}_{2}\right)$ with no $\mathrm{pH}$ control throughout the culture period. Controls were set up in the same manner, with only the growth media and no microalgal species in each case. The culture $\mathrm{pH}$ and temperature were monitored with Ohuas Starter300 instrument (Ohaus Corporation, USA). The analysis for residual nitrate- $\mathrm{N}$ concentration in the culture was conducted using the colorimetric method after nitration of salicylic acid as developed by Cataldo et al. [25]. Briefly, $10 \mathrm{~mL}$ microalgae culture was centrifuged at $4500 \mathrm{rpm}$ for $12 \mathrm{~min}$ and the supernatant collected. A sample aliquot of $50 \mu \mathrm{L}$ was pipetted into a clean tube with $200 \mu \mathrm{L}$ salicylic acid- $\mathrm{H}_{2} \mathrm{SO} 4$ mixture $(5 \%, \mathrm{w} / \mathrm{v})$ and mixed thoroughly by agitation. It was followed by a 10 -min incubation at room temperature. Then $2 \mathrm{~mL} \mathrm{NaOH}(4 \mathrm{M})$ was added to the solution and the mixture was shook and incubated for $20 \mathrm{~min}$ at room temperature. A Cary $60 \mathrm{UV}-\mathrm{Vis}$ (Agilent Technologies, USA) spectrophotometer was used to measure the absorbance at $410 \mathrm{~nm}$. To assess nitrate-N levels in the sample, the absorbance readings achieved were back-plotted on a previously constructed nitrate calibration curve $\left(y=0.0132 x-0.0022 ; R^{2}=9938\right)$. The blank sample was treated with $96 \% \mathrm{H}_{2} \mathrm{SO} 4$ without salicylic acid, followed by $4 \mathrm{M} \mathrm{NaOH}$ as described above. 


\subsection{Cell density, growth kinetics and $\mathrm{CO}_{2}$ biosequestration rate}

Microalgae biomass measurements were taken every $48 \mathrm{~h}$. Briefly, $10 \mathrm{~mL}$ of well-mixed microalgae culture was aseptically weighed in a dried pre-weighed falcon tube using analytical Ohaus balance to 3 decimal places (Ohaus Corporation, USA). The culture was centrifuged at $7000 \mathrm{rpm}$ for $10 \mathrm{~min}$ after which the supernatant was carefully discarded. The residual biomass was washed twice with deionised water, kept at $-20{ }^{\circ} \mathrm{C}$ and subsequently moved to $-80{ }^{\circ} \mathrm{C}$ for $30-50 \mathrm{~min}$ before freezedrying. Frozen samples were dried with lyoQuest freeze drier at (Telstar, Japan) stable operating conditions of $-54.8{ }^{\circ} \mathrm{C}$ and $0.287 \mathrm{nBar}$ for $24 \mathrm{~h}$. The net biomass weight was determined after re-weighing the dried samples according to Eq. (1):

$\mathrm{DWB}=\mathrm{B}-\mathrm{F}$

where $B$ and $F$ represents the gross biomass weight and falcon tube weight respectively whilst $D W B$ is the net dry weight biomass of the isolates.

Microalgae culture aliquots $(2 \mathrm{~mL})$ were collected every $48 \mathrm{~h}$ and diluted with BG-11 or BBM medium to a maximum optical density (OD) of less than 1.0. The OD was determined at a wavelength of $750 \mathrm{~nm}$ using Eppendorf BioSpectrometer ${ }^{\circledR}$ kinetic (Eppendorf, Germany), and the instrument was blanked with sterilised BG-11 or BBM. The actual OD was determined by multiplying the spectrometric results with the dilution factor.

The respective microalgal biomass productivity (BP), specific growth rate $(\mu)$ and $\mathrm{CO}_{2}$ biosequestration rate $\left(\mathrm{R}_{\mathrm{CO} 2}\right)$ were determined according to Eqs. (2), (3) and (4) below:

$\mathrm{BP}\left(\mathrm{g} \mathrm{day}^{-1}\right)=\frac{\mathrm{DWB}_{2}-\mathrm{DWB}_{1}}{\mathrm{t}_{2}-\mathrm{t}_{1}}$

$\boldsymbol{\mu}\left(\mathrm{day}^{-1}\right)=\frac{\ln \left(\mathrm{DWB}_{2} / \mathrm{DWB}_{1}\right)}{\left(\mathrm{t}_{2}-\mathrm{t}_{1}\right)}$

$\mathrm{R}_{\mathrm{CO}_{2}}\left(\mathrm{gCO}_{2} \mathrm{~L}^{-1} \mathrm{day}^{-1}\right)=\mathrm{C}_{\mathrm{avg}} \times \mathrm{BP} \times\left(\frac{\mathrm{MW}_{\mathrm{CO}_{2}}}{\mathrm{MW}_{\mathrm{C}}}\right)$

where $D W B$ is the dry weight biomass at the time of measurement $\left(\mathrm{t}_{2}\right)$ and the beginning of the culture $\left(\mathrm{t}_{1}\right)$. $M W \mathrm{co}_{2}$ and $M W_{\mathrm{C}}$ represent the molecular weights of $\mathrm{CO}_{2}$ and $\mathrm{C}$ (elemental), respectively. $\mathrm{C}_{\text {avg }}$ is the mean elemental carbon content of the respective microalgae biomass determined by an elemental analyser.

\subsection{Microalgal biomass harvesting, biochemical and elemental analysis}

All unialgal cultures were harvested after 16 days with a centrifuge at $7000 \mathrm{rpm}$ for $10 \mathrm{~min}$ and freeze-dried.

\subsubsection{Total lipid and carbohydrate content and fatty acid methyl esters measurement}

Microalgae carbohydrate was determined by phenol-sulfuric acid method of Dubois et al. [26] with glucose as a standard. Ten milligrams (mg) of freeze-dried powdered microalgae biomass was reconstituted in an $8-\mathrm{mL}$ deionised water, vortexed, resulting in a concentration of $1.25 \mathrm{mg} / \mathrm{mL}$. One millilitre of aliquot was transferred into a clean tube. One millilitre of $50 \mathrm{~g} \mathrm{~L}^{-1}$ phenol solution and $5 \mathrm{~mL}$ concentrated $\mathrm{H}_{2} \mathrm{SO}_{4}(96-98 \%)$ were added in turns and heated for 5-7 min at $90{ }^{\circ} \mathrm{C}$. The resultant solution was then cooled at room temperature (RT) for $15 \mathrm{~min}$ and measured at a wavelength of $490 \mathrm{~nm}$ with Cary $60 \mathrm{UV}-\mathrm{Vis}$ (Agilent Technology, USA) spectrophotometer using various glucose standards concentrations. The carbohydrate (glucose) content was then computed from the pre-calibrated glucose standard curve $\left(y=0.9044 x-0.0392 ; R^{2}=9978\right)$.

The total lipid was determined with a single-step method developed by Axelsson and Gentilia [27]. Briefly, $10 \mathrm{mg}$ freeze-dried microalgae biomass was reconstituted in $5 \mathrm{~mL}$ methanol-chloroform $(1: 2 \mathrm{v} / \mathrm{v})$ and vortexed until the microalgae biomass was evenly distributed in the mixture. The mixture was sonicated briefly, after which $2 \mathrm{~mL}$ of $0.9 \%$ $\mathrm{NaCl}$ solution was added and finally centrifuged at $7000 \mathrm{rpm}$ for $10 \mathrm{~min}$. Microalgae biomass debris formed a thin layer between the upper organic phase and the lower lipid phase. A Pasteur pipette was then used to gently remove the lower lipid phase into a $15-\mathrm{mL}$ dried pre-weighed glass vial. The residue was re-extracted twice with $2.0 \mathrm{~mL}$ methanol-chloroform $(1: 1, \mathrm{v} / \mathrm{v})$ as indicated above. The solvent in the vial was oven-dried at $60{ }^{\circ} \mathrm{C}$ until a constant lipid weight was gained and the percentage total lipid content determined by gravimetric method according to Eq. (5):

$\%$ Microalgal Lipid total $_{1}=\frac{\mathrm{W}_{\text {lipid extracted }}(\mathrm{mg})}{\mathrm{W}_{\text {microalgal biomass }}(\mathrm{mg})} \times 100$

where $W_{\text {lipid extracted }}$ and $W_{\text {microalgal biomass }}$ are weight of the microalgal biomass and lipid extracted in milligrammes, respectively.

Fatty acid methyl esters (FAME) were prepared by direct transesterification method developed by Lepage and Roy [28] modified by Van Wychen and Laurens [29] and analysed with a high-resolution gas chromatograph-mass spectrometer (GC-MS) (Agilent Technologies, USA). 
Briefly, $0.2 \mathrm{~mL}$ chloroform-methanol $(2: 1, \mathrm{v} / \mathrm{v})$ was added to $5 \mathrm{mg}$ freeze-dried powdered microalgal biomass contained in a $1.5-\mathrm{mL}$ GC-MS vials. This was followed by the addition of $0.025 \mathrm{~mL}$ of $10 \mathrm{mg} / \mathrm{mL}$ methyl tridecanoate (internal standard) and $0.3 \mathrm{~mL}$ of $0.6 \mathrm{M}$ methanolic- $\mathrm{HCl}$, respectively, and vortexed. The vial was heated at $85^{\circ} \mathrm{C}$ for $1 \mathrm{~h}$ and cooled at RT subsequently. One millilitre hexane was added to the cooled mixture, vortexed and allowed to stand for $1 \mathrm{~h}$ at RT to enable proper phase separation. The organic (upper) phase was later collected and analysed with an Agilent Technologies 7890B GC system (B.02.04.2) equipped with mass spectrometer with following operating conditions capillary column-DB-WAX $30 \mathrm{~m} \times 0.25 \mathrm{~mm} \times 0.25 \mu \mathrm{m}$; oven temperature $-100{ }^{\circ} \mathrm{C}$ for $1 \mathrm{~min}, 25^{\circ} \mathrm{C} / \mathrm{min}$ up to $200{ }^{\circ} \mathrm{C}$ and hold for $5{ }^{\circ} \mathrm{C} / \mathrm{min}$ up to $250{ }^{\circ} \mathrm{C}$ and hold for $7 \mathrm{~min}$; carrier gas flow $-1 \mathrm{~mL} / \mathrm{min}$ helium; sample injection $-1 \mu \mathrm{L}$ at 10:1 split ratio. The FAME components were separated and detected based on their retention time.

Biodiesel quality parameters, including the saponification number (SN), the iodine number (IV) and the cetane number $(\mathrm{CN})$, were calculated in accordance with Zhou et al. [30] and represented by Eqs. (6), (7) and (8), respectively.

$$
\begin{aligned}
& \mathrm{SN}=\sum\left(560 \times \% \mathrm{RFAME}_{\mathrm{C}}\right) / \mathrm{MW}_{\mathrm{C}} \\
& \mathrm{IV}=\sum\left(254 \times \mathrm{db} \times \% \mathrm{FAME}_{\mathrm{C}}\right) / \mathrm{MW}_{\mathrm{C}} \\
& \mathrm{CN}=46.3+\left(\frac{548}{\mathrm{SN}}\right)-(0.225 \mathrm{IV})
\end{aligned}
$$

where $\%$ RFAME $_{\mathrm{c}}$ and $\mathrm{MW}_{\mathrm{c}}$ are the relative percentage abundance of individual FAME components and their molecular weights, respectively.

\subsubsection{Elemental constituents and protein estimation}

The chemical constituent of microalgal biomass was determined with calibrated Flash 2000 organic elemental analyser (Thermo Fisher Scientific Inc, Japan). The calibration standards included cystine $(\mathrm{N}=11.64 \%, \mathrm{C}=30.10 \%$, $5.02 \%, \mathrm{~S}=26.62 \%)$, BBOT $(\mathrm{N}=6.54 \%, \mathrm{C}=72.59 \%, 6.06 \%$, $\mathrm{S}=7.43 \%)$, methionine $(\mathrm{N}=9.35 \%, \mathrm{C}=40.26 \%, 7.37 \%$, $\mathrm{S}=21.46 \%)$ and sulfanilamide $(\mathrm{N}=16.24 \%, \mathrm{C}=41.81 \%$, $4.72 \%, \mathrm{~S}=18.68 \%$ ). Briefly, about $2 \mathrm{mg}$ dried sample was weighed in a tin foil cup and combusted at $950{ }^{\circ} \mathrm{C}$ with pure oxygen and helium as a carrier gas. Percentage nitrogen was then multiplied by 4.78 to obtain the crude protein content of the dry microalgal biomass [31]. The 4.78 factor was used in this work to estimate the protein content because it has been frequently used in related studies as a reliable factor for such conversions, especially with regards to green microalgae
[32-34]. The percentage of carbon, hydrogen and sulphur were also analysed.

\subsection{Statistical analysis}

Triplicate studies were performed unless otherwise stated and values were expressed as mean \pm standard deviation. Data were subjected to $T$-test at significance $p \leq 0.05$ with Excel (Microsoft Office 2016; Microsoft; USA) and IBM Statistical package for Social Sciences (SPSS version 20.0 for windows; IBM Corporation; USA) and represented graphically with OriginLab software (Version 8.5 for Windows; OriginLab Corporation; USA). Standard deviation (SD) values are depicted in the graphs as bars.

\section{Results and discussion}

\subsection{Isolation and identification of microalgal strains}

In order to obtain microalgal strains with novel properties, bioprospecting of native microalgae from unexplored biodiverse aquatic environments is essential. Thus, composite freshwater samples were taken from Killarney Country Club, Johannesburg, Gauteng Province-South Africa, which is new to algae research in South Africa. This sampling site was chosen based on the microalgal abundance on the "Golfhazard" water at that particular time of the year.

The sample was collected when the water was at a temperature of $20{ }^{\circ} \mathrm{C}$ and $\mathrm{pH} 8.6$ which was noted to be within the optimal conditions for microalgae growth [35] and between 10 and 11 am when most of the species are expected to have come up to the water surface. Microalgae isolation is a core requirement for obtaining monocultures, and represents the major initial hurdle towards selecting species with novel qualities. Nevertheless, isolating these microalgal strains from their natural habitats may demand the use of various nutrient media with different compositions to ensure the optimal growth of specific strains for complete recovery [36]. Our study used only BG-11 and BBM media for this purpose since these media are reportedly capable of supporting the growth of most microalgal species from different natural habitats [36-38]. A total of 4 microalgal isolates out of the initial 8 survived on both the agar-based media and their respective liquid media, but the other four failed to do so in the liquid media. These four isolates include 3 (UJEAS1, UJEAS4 and UJEAS7), which were successfully cultured in BG-11 media, whilst the remaining 1 (UJEAS8) was adequately supported with BBM media. Of the 4 isolates, we considered 2 for downstream analysis based on their initial promising growth rates and their ability to remain buoyant in their respective nutrient media, BG-11 media thrived-UJEAS4 and BMM media 
thrived-UJEAS8. In addition, UJEAS4 and UJEAS8 selected for confirmatory molecular identification and further culturing to evaluate their capabilities to remove nitrogen, fix $\mathrm{CO}_{2}$ as well as their potential for use as raw materials in biofuel and nutraceutical industries.

The light microscopic examination of the selected microalgal species revealed distinct morphologies indicated by a difference in cell structure and size. Images captured during the morphological analysis with the light microscope are represented in Fig. 1a and b with some key observed features of UJEAS4 (Fig. 1a) as having spherical shaped cells with no flagella and the average sizes varied between 3 and 4 and 5 and $6 \mu \mathrm{m}$, which is a common feature of the genus Chlorella $[4,39,40]$.

Whilst the cells of the isolate-labelled UJEAS8 (Fig. 1b) were spindle shaped with acute cell poles, typical of genus Acutodesmus (Scenedesmus) [41]. The light microgram of UJEAS8 also showed 2- to 4-celled coenobia with no-mucilage coverings, alternates on two levels and ranges in sizes between 4 and 14 and 7 and $17 \mu \mathrm{m}$ on the average.

Nevertheless, conclusions drawn with morphological analysis alone can be ambiguous, inadequate and misleading because of the highly publicised phenomenon of analogous morphology predominant among the diverse categories of microalgae [42]. Hence, ITS2 sequencing was employed in this study as one of the reliable barcoding techniques for identifying the microalgal isolates to a precise and accurate species level. The amplified ITS2 genes of both UJEAS4 and UJEAS8 isolates were above 780 base-pairs (bp) in size. UJEAS4 and UJEAS8 isolates were further found to relate to Chlorella sorokiniana with similarities $>97 \%$ and Acutodesmus reginae with $>99 \%$, respectively, when their sequences were subjected to BLASTn analysis. Previous studies have reported that homology levels of $97-100 \%$ can be used to establish the identity of sample species or strains with reported species in the NBCI database, especially when the $E$-values are $<0.00$ [43-46].

A subsequent phylogenetic analysis shown in Fig. 2a, b confirmed that UJEAS4 is closely related to Chlorella sorokiniana [39, 47] whilst UJEAS8 was Acutodesmus reginae [21] with bootstrap values of $69 \%$ and $95 \%$, respectively.

It is important to note that the genus of isolate UJEAS8 has been under review in recent years. Acutodesmus was previously considered a subgenus of Scenedesmus until Tsarenko and Petlevanny [48], asserted that Scenedesmus and Acutodesmus are paraphyletic and must be upgraded to a genus. Hegewald et al. [49] further validated this and pushed for the acceptance of Acutodesmus as a genus through their work. Later, Wynne and Hallan [50] challenged the name Acutodesmus describing it as illegitimate and hence made a case for the name Tetradesmus which was earlier proposed by Smith [51] and hence Tetradesmus became the current accepted genus name. However, the algological community currently considers the genus names Scenedesmus, Acutodesmus and Tetradesmus as heterotypic synonyms, with Scenedesmus as the basionym. UJEAS 8 was grouped among Chlorophyta (phylum), Chlorophyceae (class), Sphaeropleales (order) and Scenedesmaceae (family) Tetradesmus (genus). Therefore, our study will subsequently refer to UJEAS8 or Tetradesmus (Acutodesmus) reginae as Tetradesmus reginae. UJEAS4 shares the same phylum with isolate UJEAS8 (which qualifies them as green algae) but differs in subsequent classifications as follows with unique characteristics: Trebouxiophyceae (class), Chlorellales (order), Chlorellaceae (family) and Chlorella (genus).
Fig. 1 Light micrographs of the two wild Southern Africa microalgal isolates in this study a UJEAS4 and b UJEAS8.

Magnification: $400 \times$ (a)

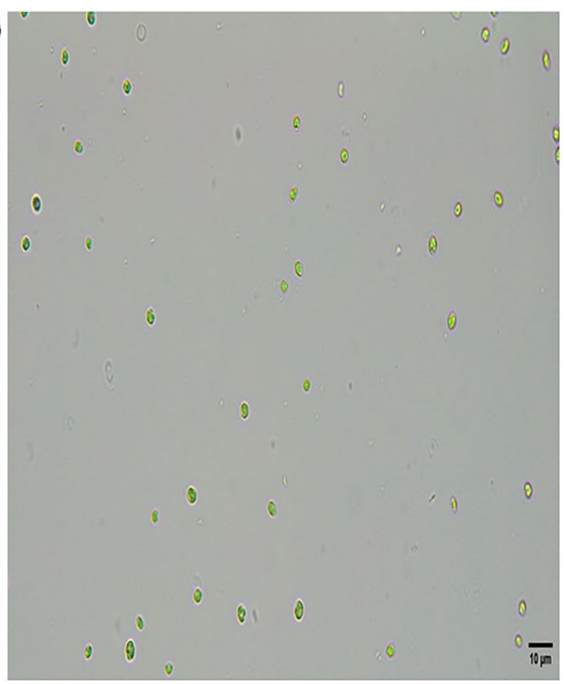

(b)

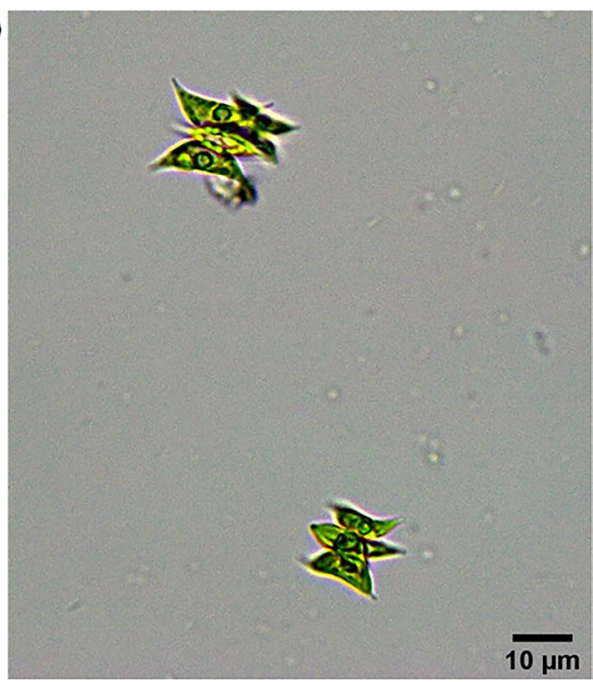



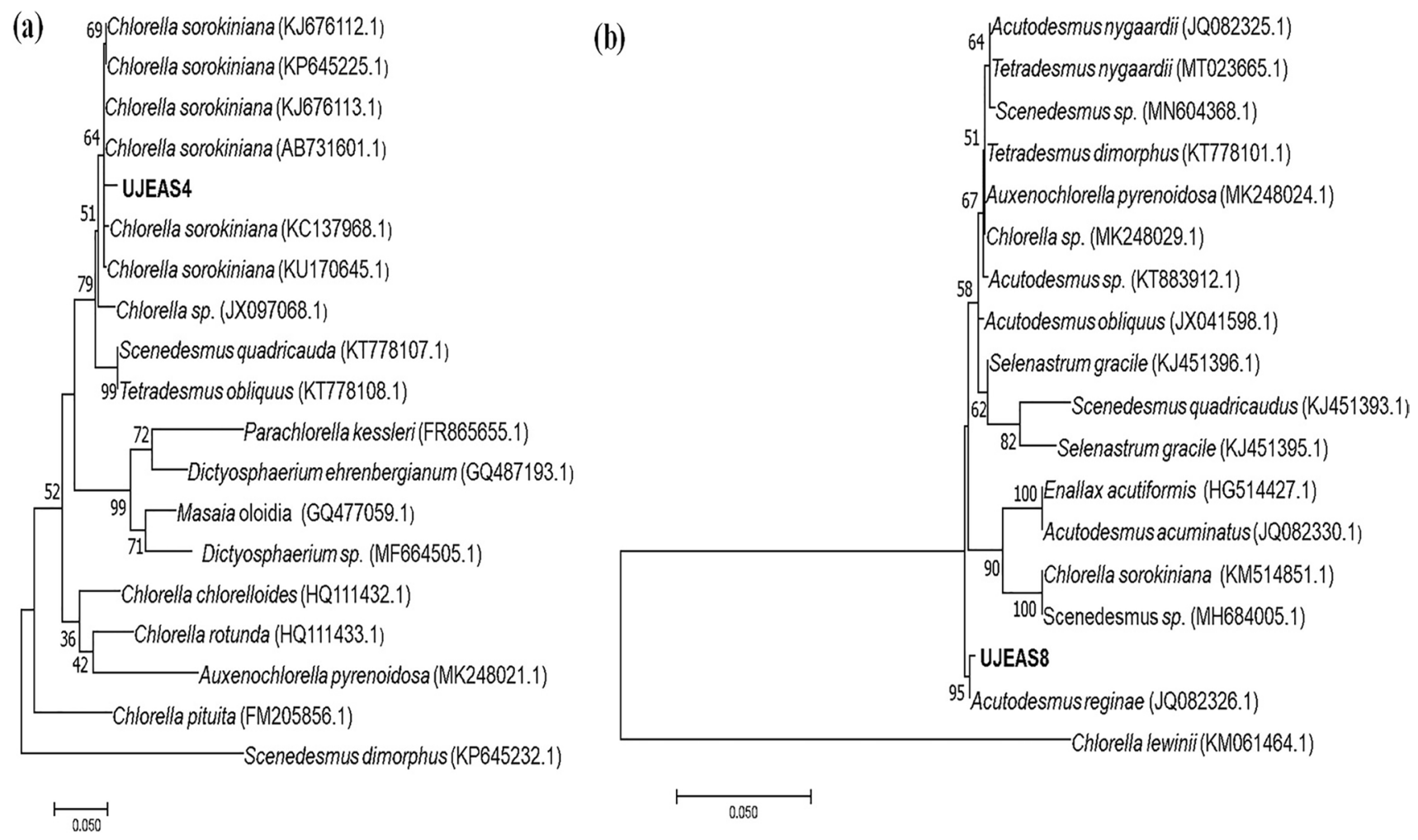

Fig. 2 Phylogenetic tree of microalgal isolates a UJEAS4 and b UJEAS8 based on ITS2 sequence constructed by ML algorithm. Bootstrap numbers below 50 were not shown on the tree. The numbers on nodes indicate bootstrap values after 1,000 replicates expressed in percentages

\subsection{Biomass productivity, growth kinetics and $\mathrm{CO}_{2}$ biosequestration rates}

High microalgal growth rate, rapid biomass accumulation and excellent carbon fixation rates are crucial requirements for selecting a particular microalgae species as a potential bioresource with climate change mitigation capabilities $[52,53]$. Therefore, our work assessed each microalgal isolate cultivated in their respective BG-11 and BBM media for their biomass accumulation abilities, growth kinetics and $\mathrm{CO}_{2}$ biosequestration rates and presents the results in Fig. 3 .

It can be inferred in Fig. 3 that the growth pattern of the two microalgal species is expected to be in line with the four conventional phases, namely, lag, exponential, stationary and declining phases but the first two phases were notable. This observation could be due to the fact that the isolates' growth culture was stopped prior to significant nutrient stress being experienced by the algal cells. Even so, whilst the nitrate levels in the culture medium did decrease and became completely consumed by the end of the culture period as it was in the case of $T$. reginae; the isolate might still have been thriving on intracellular nitrogen reserves [54]. The measured dry wet biomass (DWB) and the optical cell densities at $750 \mathrm{~nm}$ of all monocultures also showed a linear regression association per Eqs. (9) and (10) and respective strong $R^{2}$ values.cy4

$$
\mathbf{a ~ D W B}_{\text {C.sorokiniana }}=1.8923\left(\mathrm{OD}_{750}\right)+0.2058 ; R^{2}=0.9912
$$

b DWB $_{\text {T.reginae }}=1.2571\left(\mathrm{OD}_{750}\right)+0.1289 ; R^{2}=0.9872$

Our observations revealed that there was a significant difference $(p<0.05)$ in biomass productivity, specific growth rate and doubling times among the isolates under cultivation (Table 1).

T. reginae, which was cultured in BBM out-performed the BG-11-cultivated $C$. sorokiniana, in the mentioned growth parameters. Tetradesmus reginae showed a specific growth rate $(\mu)$ of $0.20 \pm 0.009 /$ day with a shorter doubling time $(\mathrm{d} 2)$ of $3.5 \pm 0.158$ days whilst the $\mu$ for $C$. sorokiniana was lower at $0.14 \pm 0.015 /$ day with a relatively longer $\mathrm{d} 2$ of $4.8 \pm 0.544$ / day. This growth kinetics eventually culminated in biomass productivity of $0.2 \pm 0.004 \mathrm{~g} \mathrm{~L}^{-1} \mathrm{day}^{-1}$ for $T$. reginae and $0.128 \pm 0.003 \mathrm{~g} \mathrm{~L}^{-1} \mathrm{day}^{-1}$ for $C$. sorokiniana. Thus, T. reginae stands a better chance as a potential bioresource between the two, since biomass productivity is a key selection factor in that regard. In addition, our study recorded maximum biomass concentrations of $3.32 \pm 0.051$ and $2.21 \pm 0.038 \mathrm{~g} \mathrm{~L}^{-1}$ 

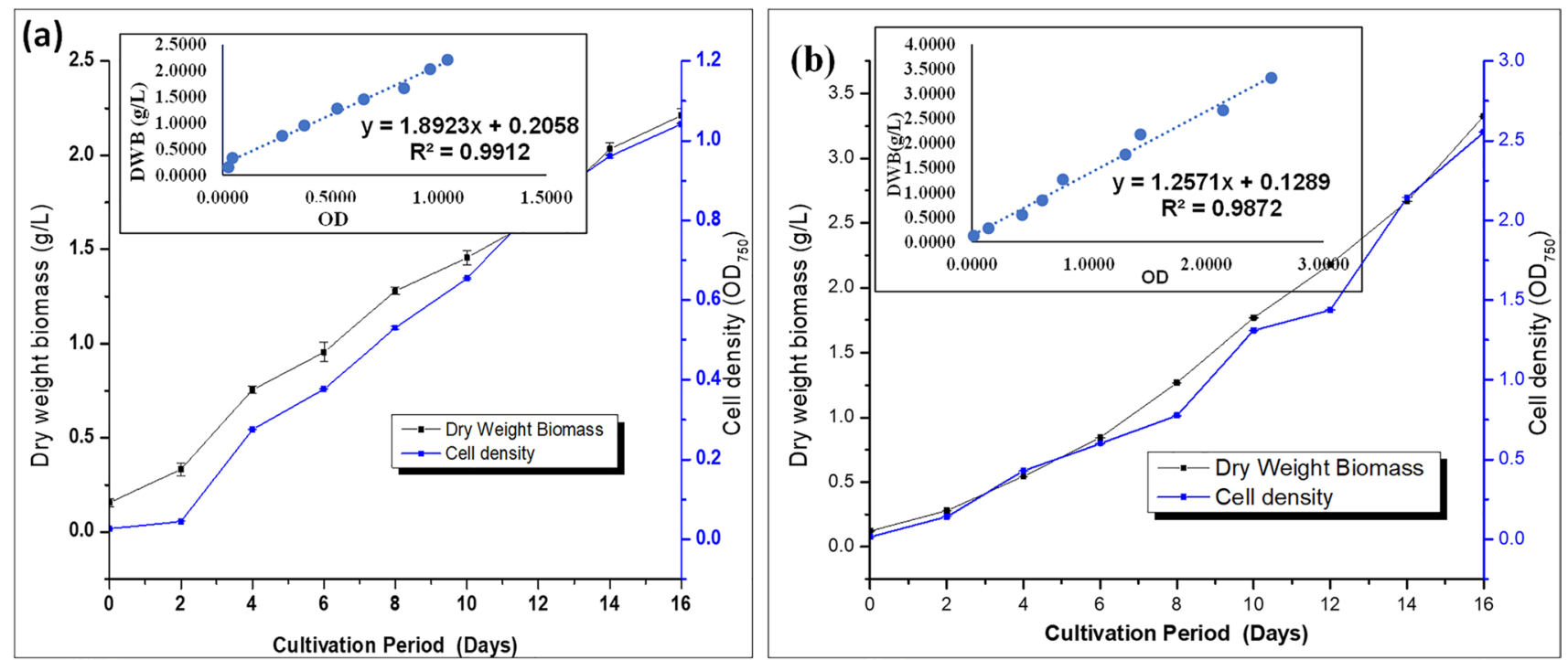

Fig. 3 Linear relation between dry weight microalgae biomass and respective optical cell densities for a C. sorokiniana and b T. reginae

Table 1 Biomass production, growth kinetics and $\mathrm{CO}_{2}$ biosequestration rate of microalgal isolates

\begin{tabular}{llllllll}
\hline Microalgal strain & Culture medium & $\begin{array}{l}\text { Culture } \\
\text { duration } \\
\text { (days) }\end{array}$ & $\begin{array}{l}\text { Max. biomass } \\
\text { conc }\left(\mathrm{g} \mathrm{L}^{-1}\right)\end{array}$ & $\begin{array}{l}\text { Biomass } \\
\text { productiv- } \\
\text { ity, } \mathrm{BP} \\
\left(\mathrm{g} \mathrm{L}^{-1} \mathrm{day}^{-1}\right)\end{array}$ & $\begin{array}{l}\text { Specific growth } \\
\text { rate, } \mu \text { (day) }\end{array}$ & $\begin{array}{l}\text { Biomass doubling } \\
\text { time, } \mathrm{d}_{2}\left(\mathrm{days}^{2}\right)\end{array}$ & $\begin{array}{l}\mathrm{CO}_{2} \text { sequestration rate } \\
\left(\mathrm{gCO}_{2} \mathrm{~L}^{-1} \mathrm{day}^{-1}\right)\end{array}$ \\
\hline C. sorokiniana & $\mathrm{BG}-11$ & 16 & $2.21 \pm 0.038$ & $0.128 \pm 0.003$ & $0.14 \pm 0.015$ & $4.8 \pm 0.544$ & $23.05 \pm 0.711$ \\
T. reginae & $\mathrm{BBM}$ & 16 & $3.32 \pm 0.051$ & $0.200 \pm 0.004$ & $0.20 \pm 0.009$ & $3.5 \pm 0.158$ & $31.52 \pm 0.600$ \\
\hline
\end{tabular}

for T. reginae and C. sorokiniana, respectively. Though the biomass concentration for $C$. sorokiniana might appear in this study to be relatively lower, it was two times higher than what Lugo et al., [55] reported for the same species for unsupplemented BG-11, under uncontrolled $\mathrm{pH}$ and air bubbling. This could be attributed to an optimum $\mathrm{CO}_{2}$, nitrate-nitrogen and light exposure in the current study. A similar argument could be made for T. reginae when its biomass concentrations are compared to other species belonging to the Scenedesmus/Acutodesmus genus in other studies under similar conditions [56, 57]. The microalgae isolates were reported to tolerate a high temperature up to $37^{\circ} \mathrm{C}$ and could also thrive in a heterotrophic environment $[58,59]$. Even though, culture medium and conditions as well as each microalgal strain's nutrient requirement could also influence the differences between each microalgae productivity [60], this was not our study's focus, and there is a need to further explore this to ensure higher growth rates and improved metabolite production.

The $\mathrm{CO}_{2}$ biosequestration rates of the two microalgal isolates were also found to be significantly different with $T$. reginae biofixing dissolved $\mathrm{CO}_{2}$ at the rate of $31.52 \pm 0.600 \mathrm{gCO}_{2} \mathrm{~L}^{-1}$ day $^{-1}$ followed by $23.05 \pm 0.711$ $\mathrm{gCO}_{2} \mathrm{~L}^{-1}$ day $^{-1}$ for $C$. sorokiniana, respectively. Compared with high-performing $\mathrm{CO}_{2}$-fixing microalgae reported in literature [12], the isolates demonstrated reasonably high biosequestration rates but our studies did not assess their $\mathrm{CO}_{2}$ tolerance rates. Notwithstanding that fact, our isolates may be considered potential excellent $\mathrm{CO}_{2}$ mitigation options in reducing the current global high atmospheric $\mathrm{CO}_{2}$ levels if cultivated under optimal conditions.

\subsection{Nutrient consumption and $\mathrm{pH}$ variations}

The observed rates of nitrogen consumption vis-a-vis $\mathrm{pH}$ variation in the cultures every $48 \mathrm{~h}$ for 16 days is presented in Fig. 4a, b.

Generally, there was a positive correlation between biomass productivity and the variations in culture $\mathrm{pH}$ and a negative correlation between culture $\mathrm{pH}$ and nitrate-N consumption or depletion in both cultures under the photoautotrophic cultivation period. In other words, changes in the culture $\mathrm{pH}$, was a sign that nitrate-nitrogen was getting assimilated by the microalgal species, resulting in biomass accumulation [61, 62]. However, the initial concentration of nitrate- $\mathrm{N}$ in the microalgal cultures could impact the biomass output of the two isolates. This observation could explain why T. reginae with an initial culture nitrate-N 
Fig. 4 Biomass yields and nitrate-N consumption with corresponding culture $\mathrm{pH}$ variations and their respective controls of a $C$. sorokiniana and b $T$. reginae
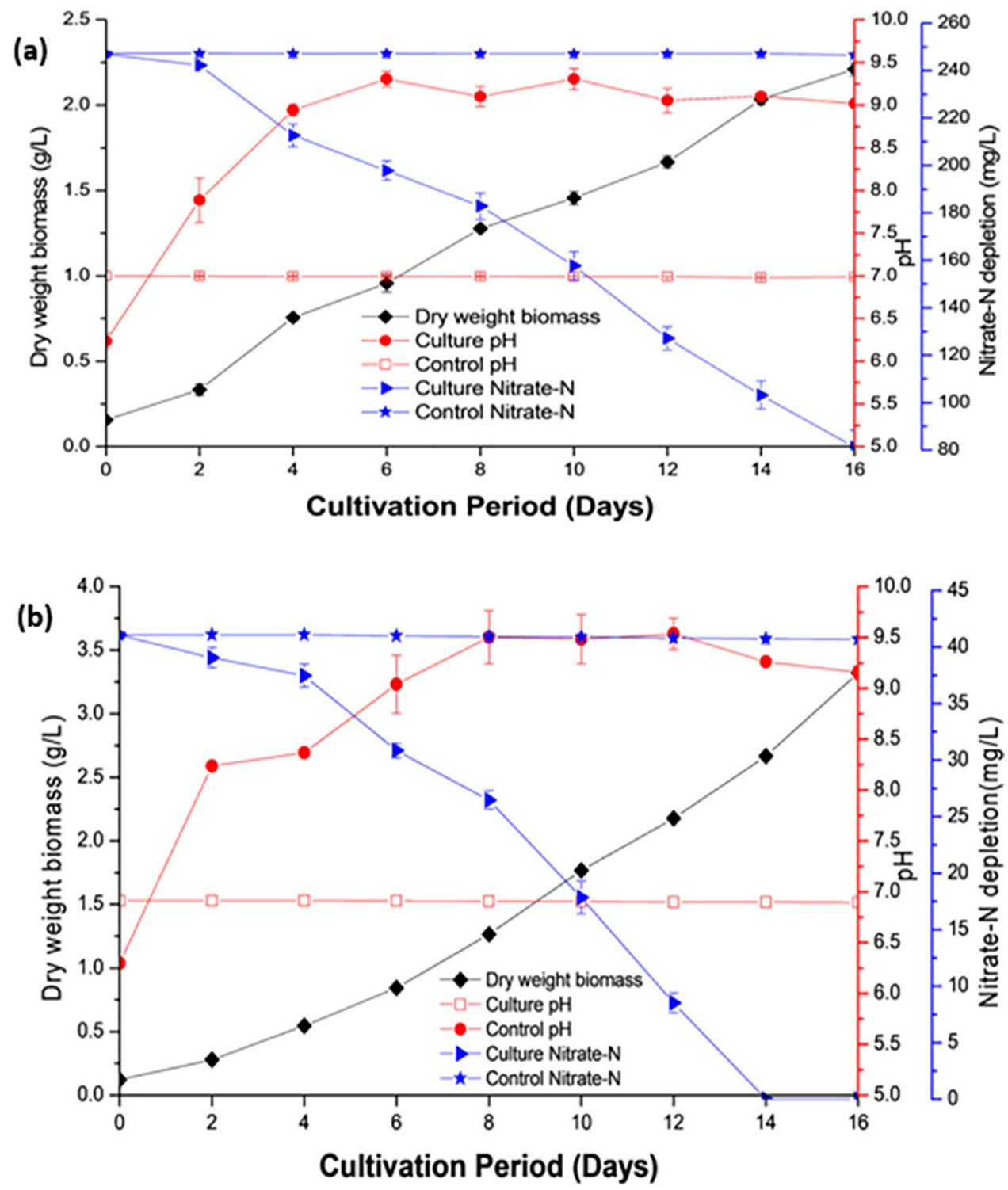

concentration of about $41 \mathrm{mg} \mathrm{L}^{-1}$ (in BBM) recorded higher maximum biomass output in comparison to $C$. sorokiniana with initial culture nitrate-N levels of around $247 \mathrm{mg} \mathrm{L}^{-1}$ each (in BG-11). Though earlier reports on initial culture nitrate-N levels' have an effect on microalgal growth, maybe contrary, there is a strong suggestion that an increase in initial culture nitrate-N levels stimulate nitrogen reductase and nitrite reductase activities [63]. This may lead to ammonium accumulation and its related toxic effect on microalgal cells with an eventual reduction in cell growth or increase in cell death [64]. Whilst Wang and Lan [65] showed in their study that increasing initial culture nitrate-N levels $\left(218 \mathrm{mg} \mathrm{L}^{-1}\right)$ reduced microalgae cell growth of green alga Neochloris oleaobundans, Ogbonna et al. [66] reported no significant change in green microalgal species, $C$. sorokiniana and Spirula platensis with an initial culture nitrate-N levels of $700 \mathrm{mg} \mathrm{L}^{-1}$. It is also very important to situate this argument in the broader context of other prevailing culture conditions $\left(\mathrm{pH}\right.$, light intensity, temperature, $\mathrm{CO}_{2}$ and photoperiod) and the physiology of the microalgal cells used which in most cases are not exactly the same.

The culture $\mathrm{pH}$ in this study was not controlled after initial sparging with pure $\mathrm{CO}_{2}$ gas and continuous air bubbling to supply $0.34 \% \mathrm{CO}_{2}$ (in air) and to prevent the microalgae species under cultivation from clinging to the walls of the bioreactors. At the end of the 16-day cultivation period, culture $\mathrm{pH}$ ranged from 6.24 to 9.10 and 6.30 to 9.54 for $C$. sorokiniana and $T$. reginae, respectively. This could be explained based on the source of available nitrogen (nitrate- $\mathrm{N}$ ) and the absence of excess- $\mathrm{CO}_{2}$ for microalgal photosynthesis. The observation is consistent with the findings of Wang and Curtis [67], which suggested that nitrate- $\mathrm{N}$ consumption in microalgal cultures could increase the culture $\mathrm{pH}$ due to the production of excess hydroxyl 
$\left(\mathrm{OH}^{-}\right)$ions during its assimilation. The above-mentioned process can be expressed with Eq. (11).

$\mathrm{NO}_{3}^{-}+3 \mathrm{H}_{2} \mathrm{O} \rightarrow \mathrm{NH}_{4}^{+}+2 \mathrm{O}_{2}+2 \mathrm{OH}^{-}$

The $\mathrm{pH}$ profiles of the microalgal isolates under cultivation in our study were, however, within their tolerance $\mathrm{pH}$ ranges reported in the literature, but their respective biomass productivity could have improved if $\mathrm{pH}$ was regulated at an optimal level. Ahmad et al. [68] confirmed this assertion when he recorded high biomass productivity (38 to 41 cells $\mathrm{mL}^{-1}$ day $^{-1}$ ) for a BBM cultivated Scenedesmus sp. at $\mathrm{pH}$ 7.5-8.0. Qui [69] also established that a pH 6 is suitable for $C$. sorokiniana's maximum biomass productivity $\left(0.140 \pm 0.004 \mathrm{~g} \mathrm{~L}^{-1} \mathrm{day}^{-1}\right)$.

\subsection{Biochemical composition, elemental composition and fatty acid methyl ester profile}

The isolates' biochemical composition reflects on the composition of the culture medium and the species type [70]. The composition of dry weight biomass carbohydrate, protein and total lipid, as well as fatty acid methyl ester (FAME) profile and elemental composition of the two isolates, are illustrated in Figs. 5 and 6 and Table 2.

As revealed in Fig. 5, T. reginae recorded a significantly higher $(p<0.05)$ percentage value (of dry biomass) for total lipid $(43.60 \pm 0.40 \%)$ and carbohydrate $(27.36 \pm 0.17 \%)$ when compared to the same biochemical components of C. sorokiniana (i.e., $26.80 \pm 1.20 \%$ and $23.71 \pm 0.02 \%$, respectively). This study also revealed that $C$. sorokiniana had a significantly higher $(p<0.05)$ total protein value of $44.03 \pm 1.94 \%$ in comparison to $24.75 \pm 0.36 \%$ for $T$. reginae. This observation suggests that either of the isolates could be selected based on a particular biochemical component need. For example, T. reginae is a potential biodiesel and bioethanol source, whilst $C$. sorokiniana is a food and feed supplement potential.

Nevertheless, the content analysis (Fig. 5) of C. sorokiniana showed a relatively balanced biochemical composition compared to the results of Berrejeb et al. [71] for the same species cultivated in BG-11 under similar conditions. The remarkable total lipid and carbohydrate content of $T$. reginae is the first reported, based on the authors' knowledge when cultivating BBM species. The relatively high total lipid value recorded for $T$. reginae could be attributed to the low nitrogen content (approx. $47 \mathrm{mg} \mathrm{L}^{-1}$ ) in its culture medium (BBM), which depleted around the 11-12th day of cultivation as compared to the high nitrogen levels (about $247 \mathrm{mg} \mathrm{L}^{-1}$ ) in culture medium (BG-11) of C. sorokiniana. This assertion is consistent with the conclusions from another related study that nutrients, especially exhaustion of nitrogen, trigger cascades of biochemical activities that lead to lipid accumulation in most green microalgal strains [72].
Fig. 5 Biochemical composition of microalgal isolates $C$. sorokiniana and $T$. reginae

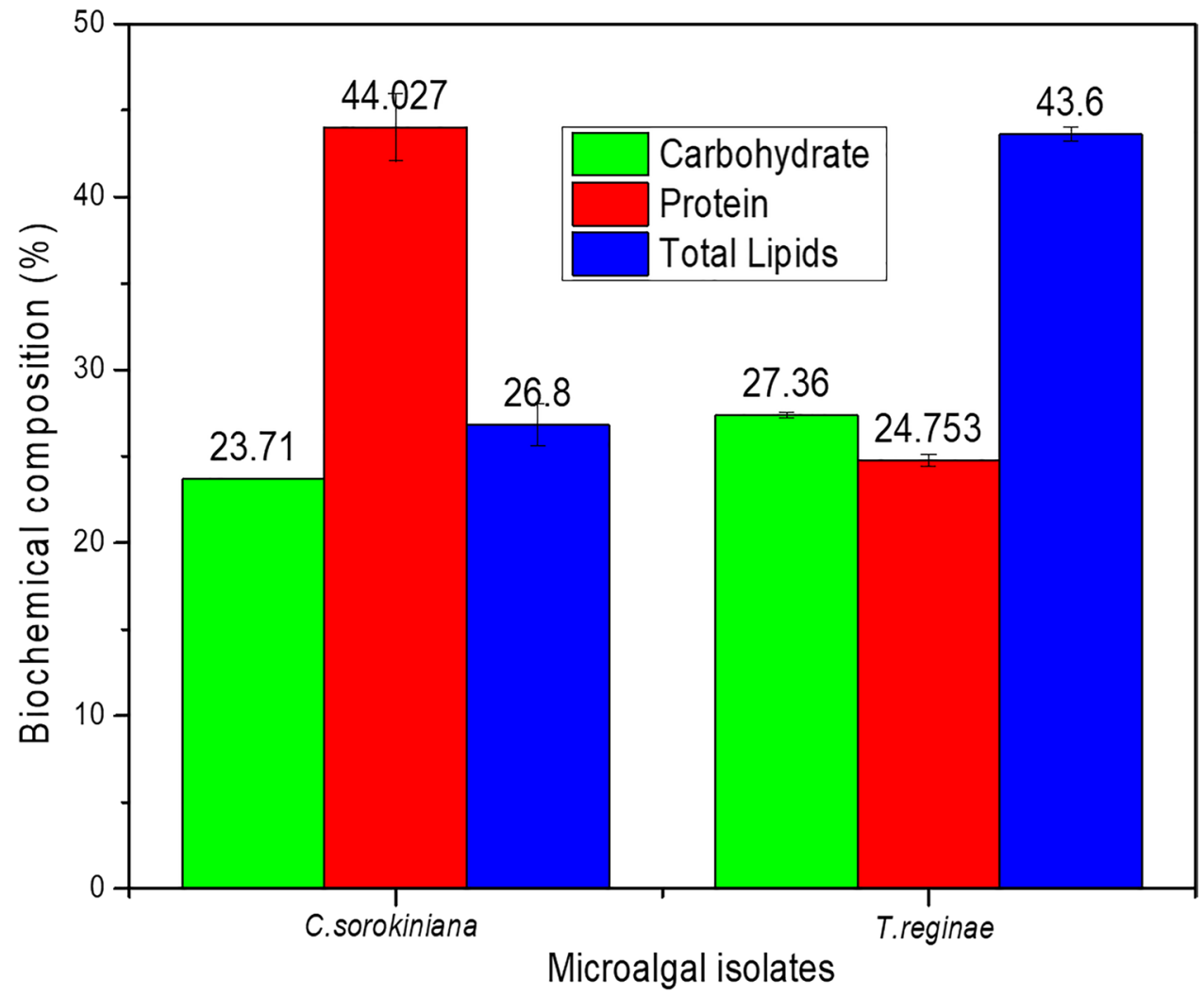


Fig. 6 Elemental composition of microalgal isolates $C$. sorokiniana and T. reginae

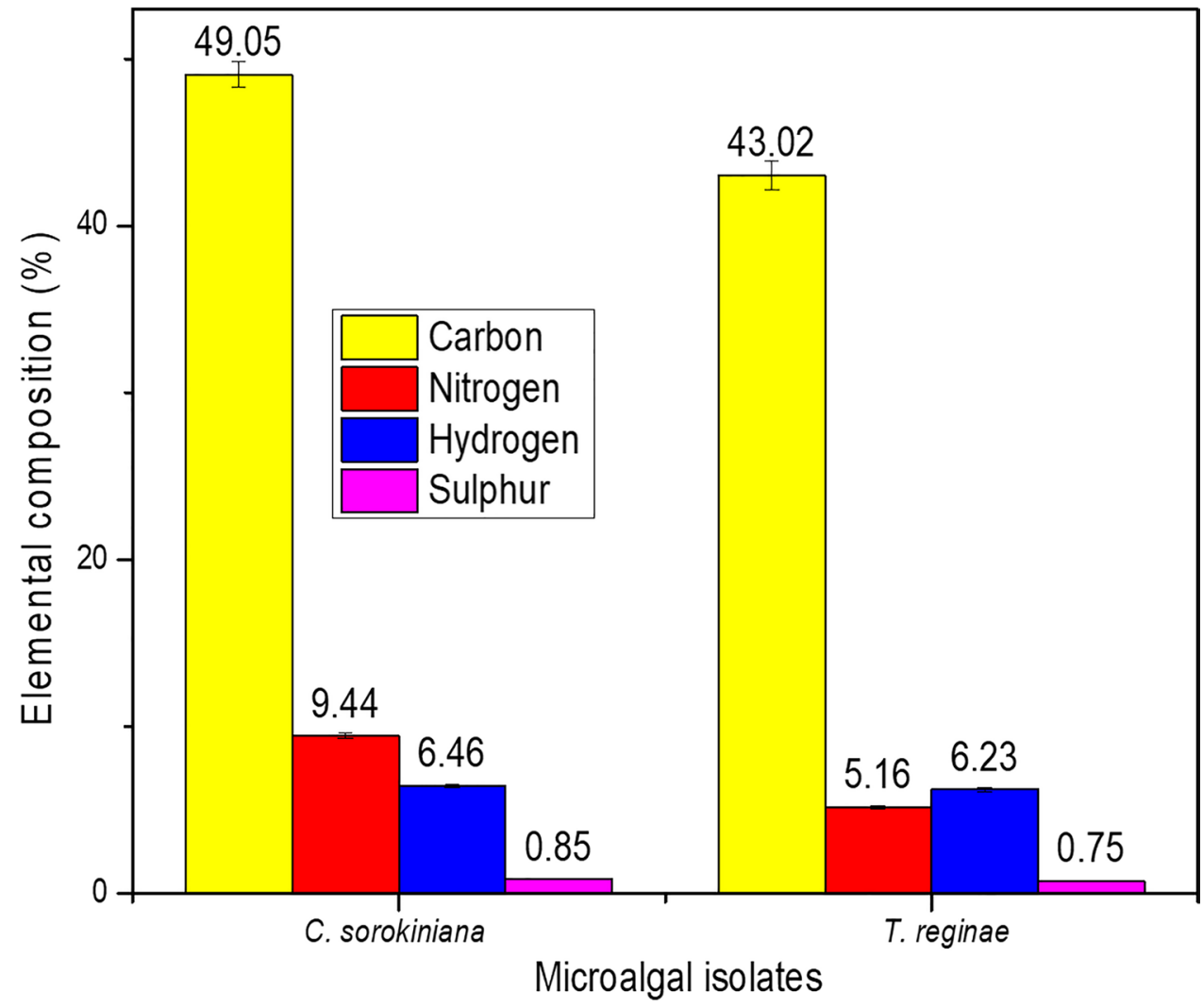

Table 2 Biochemical and elemental composition of microalgae isolates

\begin{tabular}{|c|c|c|c|c|c|c|c|c|}
\hline \multirow{2}{*}{$\begin{array}{l}\text { Microalgal } \\
\text { strain }\end{array}$} & \multirow{2}{*}{$\begin{array}{l}\text { Culture } \\
\text { medium }\end{array}$} & \multicolumn{3}{|c|}{ Biochemical content $(\%)$} & \multicolumn{4}{|c|}{ Elemental content $(\%)$} \\
\hline & & Carbohydrate & Protein & Total lipids & Carbon & Nitrogen & Hydrogen & Sulphur \\
\hline C. sorokiniana & BG-11 & $23.71 \pm 0.02$ & $44.03 \pm 1.94$ & $26.80 \pm 1.20$ & $48.99 \pm 0.56$ & $9.21 \pm 0.41$ & $6.45 \pm 0.08$ & $0.85 \pm 0.012$ \\
\hline T. reginae & BBM & $27.36 \pm 0.17$ & $24.74 \pm 0.36$ & $43.60 \pm 0.40$ & $42.98 \pm 0.60$ & $5.18 \pm 0.08$ & $6.21 \pm 0.09$ & $0.75 \pm 0.004$ \\
\hline
\end{tabular}

Sharma et al. [73] confirmed our observation when they cultivated Chlorella sp. with four different media including $\mathrm{M}_{4} \mathrm{~N}$, Fog, Bold's basal and BG-11 but found that the species in BBM produced relatively higher lipids. Sharma and colleagues also related their results to BBM's low nitrogen content, which led to early depletion [73], as a result, a stressed condition developed, which encouraged the development of more lipids. A recent report by Gonclaves et al. [74] suggested that one possible mechanism to explain the observed phenomenon is the decrease in the cellular contents of the microalgal thylakoid membrane during nitrogen starvation. This leads to the activation of the enzyme, acyl hydrolase and subsequent phospholipid hydrolysis resulting in the extracellular increase of the $\beta$-oxidation precursor, acyl-CoA fatty acid content. At the same time, diacylglycerol acyltransferase, the enzyme responsible for converting acyl-CoA to triacylglycerol (TAG), is also activated. Based on the relatively high protein, total lipid and carbohydrate contents, it can be suggested that both isolates in this study are excellent bioresources. Figure 6 illustrates the percentage total carbon $(\mathrm{C})$, nitrogen $(\mathrm{N})$, hydrogen $(\mathrm{H})$ and sulphur $(\mathrm{S})$ of the dry isolates' biomass.

The $T$-test analysis reveals a remarkable difference $(p<0.05)$ among $\mathrm{C}, \mathrm{N}, \mathrm{H}$ and $\mathrm{S}$ for all isolates. However, this study focuses on the biomass $\mathrm{C}$ and $\mathrm{N}$ content and the $\mathrm{C} / \mathrm{N}$ ratio for each isolate since the ratio can give credence to some suggested lipid accumulation mechanisms of total biomass lipid, even though the subject has not fully been explored for microalgae biomass. In simple terms, limited nitrogen availability with simultaneous sufficient organic carbon in cultures could promote the accumulation of algal lipids [75]. The usefulness of the $\mathrm{C} / \mathrm{N}$ ratio as a measure for the lipid content and the condition of individual microalgae is based on the assumption that the $\mathrm{C} / \mathrm{N}$ ratio and the lipid content within and among microalgae species will differ predictably under a wide range of conditions. The approximate calculated $\mathrm{C} / \mathrm{N}$ ratios of $C$. sorokiniana and $T$. reginae from our study were 5 and 8 , respectively. Tetradesmus reginae 
primary carbon product (sugar) biochemical pathway may have been altered to favour significant lipid synthesis (Fig. 5) as a result of the low nitrate-nitrogen available to the cells in its culture medium (BBM) as compared to that of $C$. sorokiniana. This observation is coherent with similar research findings by Ananthi et al. [76], which suggests that the higher the $\mathrm{C} / \mathrm{N}$ ratio for a particular microalgae culture, the more likely the species would accumulate lipid.

Algal biomass was harvested after the 16-day cultivation period and analysed for fatty acid methyl esters with in situ transesterification method and a high-resolution GC-MS. The results obtained are presented in Table 3.

$F A M E$, fatty acid methyl ester; $S F A$, saturated fatty acid; MUFA, mono-unsaturated fatty acid; PUFA, poly-unsaturated fatty acid; $S N$, saponification number; $I V$, iodine value; $C N$, cetane number.

This study showed that $C$. sorokiniana's fatty acid methyl ester profile contained 5 components with their relative abundances ranging from 4.7 to $35.7 \%$ whilst that of
T. reginae ranged between 0.8 and $29.8 \%$ with 12 components. Palmitic acid and linolenic acid, methyl esters were observed in appreciable abundance in both green microalgal isolates. In contrast to Sharma and colleagues' [73] results, in which BG-11 cultivated Chlorella sp. showed significant levels (15-33\%) of oleic acid, our study found no oleic acid, an essential fatty acid in green algae. However, it should be noted that Sharma's study used organic carbon source (sucrose, glucose, sodium acetate and glycerol) whilst our study relied on $\mathrm{CO}_{2}$ as the sole carbon source. Nevertheless, this observation presents a research opportunity aimed at filling the gap identified.

Saturated fatty acids (SFAs) have been described in numerous studies as biological tools for biodiesel production and microalgae are rich sources of these compounds [4]. The percentage of SFA content for $C$. sorokiniana and T. reginae corresponds to $35.73 \pm 1.13 \%$ and $29.79 \pm 1.06 \%$, respectively. Interestingly, palmitic acid is the highest and only measured SFA in the FAME profile for each isolate.

Table 3 Relative FAME component abundance and biodiesel quality indicators of microalgal isolates cultivated in artificial media

\begin{tabular}{|c|c|c|c|c|c|c|}
\hline \multirow[t]{2}{*}{ Microalgae FAME profile } & \multirow[t]{2}{*}{ Chain } & \multirow[t]{2}{*}{$\mathrm{RT}$ (min) } & \multirow[t]{2}{*}{ Formula } & \multirow[t]{2}{*}{$\begin{array}{l}\mathrm{MW} \\
\left(\mathrm{g} \mathrm{mol}^{-1}\right)\end{array}$} & \multicolumn{2}{|c|}{$\begin{array}{l}\text { Relative FAME component } \\
\text { abundance }(\%)\end{array}$} \\
\hline & & & & & $\begin{array}{l}\text { C. sorokiniana } \\
\text { (BG-11) }\end{array}$ & $\begin{array}{l}\text { T. reginae } \\
(\mathrm{BBM})\end{array}$ \\
\hline$(11 Z, 14 Z, 17 Z)-M e t h y l$ icosa-11,14,17-trienoate & $\mathrm{C} 20: 3 \operatorname{cis} 11,14,17(\mathrm{n}-3)$ & 18.85 & $\mathrm{C}_{21} \mathrm{H}_{36} \mathrm{O}_{2}$ & 320.5 & 0 & $10.04 \pm 0.46$ \\
\hline 11,14,17-Eicosatrienoic acid, methyl ester & $\mathrm{C} 20: 3(\mathrm{n}-3)$ & 18.84 & $\mathrm{C}_{21} \mathrm{H}_{36} \mathrm{O}_{2}$ & 320.5 & 0 & $10.62 \pm 0.10$ \\
\hline 11-Octadecenoic acid, methyl ester & $\mathrm{C} 18: 1$ & 18.77 & $\mathrm{C}_{19} \mathrm{H}_{36} \mathrm{O}_{2}$ & 296.5 & 0 & $2.11 \pm 0.10$ \\
\hline $\begin{array}{l}\text { 9,12,15-Octadecatrienoic acid, methyl ester, (Z,Z,Z)- } \\
\text { (linolenic acid, methyl ester) }\end{array}$ & $\mathrm{C} 18: 3(\mathrm{n}-3)$ & 20.76 & $\mathrm{C}_{19} \mathrm{H}_{32} \mathrm{O}_{2}$ & 292.5 & $12.54 \pm 5.03$ & $11.02 \pm 0.03$ \\
\hline 9,12-Octadecadienoic acid (Z,Z)-(linoleic acid) & C18: 2 cis 9,12 & 22.28 & $\mathrm{C}_{19} \mathrm{H}_{34} \mathrm{O}_{2}$ & 294.5 & $4.09 \pm 0.85$ & 0 \\
\hline $\begin{array}{l}\text { 9,12-Octadecadienoic acid, methyl ester, (E,E)- } \\
\text { (linolelaidic acid, methyl ester) }\end{array}$ & C18: 2 trans 9,12 & 18.71 & $\mathrm{C}_{19} \mathrm{H}_{34} \mathrm{O}_{2}$ & 294.5 & $5.24 \pm 0.66$ & 0 \\
\hline $\begin{array}{l}\text { 9-Octadecenoic acid (Z)-, methyl ester (oleic acid } \\
\text { methyl ester) }\end{array}$ & C18: 1 cis 9 & 14.48 & $\mathrm{C}_{19} \mathrm{H}_{36} \mathrm{O}_{2}$ & 296.5 & 0 & 0 \\
\hline Hexadecanoic acid, methyl ester (methyl palmitate) & $\mathrm{C} 16: 0$ & 16.97 & $\mathrm{C}_{17} \mathrm{H}_{34} \mathrm{O}_{2}$ & 284.5 & $35.73 \pm 1.14$ & $29.79 \pm 1.06$ \\
\hline 9,12-Hexadecadienoic acid, methyl ester & $\mathrm{C} 16: 2$ & 16.70 & $\mathrm{C}_{17} \mathrm{H}_{30} \mathrm{O}_{2}$ & 266.4 & $4.69 \pm 1.39$ & 0 \\
\hline $\begin{array}{l}\text { Methyl 4,7,10,13,16,19-docosahexaenoate (cervonic } \\
\text { acid) }\end{array}$ & $\mathrm{C} 22: 6(\mathrm{n}-3)$ & 16.66 & $\mathrm{C}_{23} \mathrm{H}_{34} \mathrm{O}_{2}$ & 342.5 & 0 & $0.77 \pm 0.07$ \\
\hline 13-Octadecenoic acid, methyl ester & C18:1 & 18.83 & $\mathrm{C}_{19} \mathrm{H}_{36} \mathrm{O}_{2}$ & 296.5 & 0 & $6.57 \pm 0.76$ \\
\hline trans-13-Octadecenoic acid, methyl ester & C18:1 trans 13 & 18.84 & $\mathrm{C}_{19} \mathrm{H}_{36} \mathrm{O}_{2}$ & 296.5 & 0 & $2.36 \pm 0.04$ \\
\hline cis-13-Octadecenoic acid, methyl ester & $\mathrm{C} 18: 1$ cis 13 & 18.84 & $\mathrm{C}_{19} \mathrm{H}_{36} \mathrm{O}_{2}$ & 296.5 & 0 & $4.51 \pm 0.03$ \\
\hline 12,13-Octadecadienoate, methyl ester & C18: 2 & 18.77 & $\mathrm{C}_{19} \mathrm{H}_{34} \mathrm{O}_{2}$ & 294.5 & 0 & $2.89 \pm 0.14$ \\
\hline 8,11,14-Heptadecatrienoate, methyl ester & $\mathrm{C} 17: 3$ & 18.84 & $\mathrm{C}_{18} \mathrm{H}_{30} \mathrm{O}_{2}$ & 278.4 & 0 & $7.4 \pm 2.46$ \\
\hline 4,7,10,13-Hexadecatetraenoic acid, methyl ester & C16:4 & 16.63 & $\mathrm{C}_{17} \mathrm{H}_{26} \mathrm{O}_{2}$ & 264.4 & 0 & $4.81 \pm 0.2$ \\
\hline \multirow[t]{7}{*}{ Phytyl, 2-methylbutanoate } & $\mathrm{C} 24: 1$ & 18.48 & $\mathrm{C}_{25} \mathrm{H}_{48} \mathrm{O}_{2}$ & 380.6 & $22.26 \pm 4.46$ & 0 \\
\hline & SFA $(\%)$ & & & & $35.73 \pm 1.13$ & $29.79 \pm 1.06$ \\
\hline & MUFA (\%) & & & & $34.81 \pm 9.50$ & $27.34 \pm 1.02$ \\
\hline & PUFA (\%) & & & & $14.02 \pm 2.9$ & $35.76 \pm 3.35$ \\
\hline & SN & & & & 122 & 146 \\
\hline & IV & & & & 36 & 75 \\
\hline & $\mathrm{CN}$ & & & & 83 & 67 \\
\hline
\end{tabular}


Poly-unsaturated fatty acids (PUFAs), on the other hand, are of special nutraceutical importance for the treatment and prevention of several ailments and prominent among them are docosahexaenoic acids (DHAs) and eicosapentaenoic acids (EPAs) [77]. These compounds were mainly found in fish oil because the fishes bioaccumulated them through the consumption of phytoplankton including microalgae in the food chain, making fish an important human nutritional source [78]. However, there is now a significant challenge associated with the sustainability of fish source; fortunately, some microalgae have been reported to contain most of these critical DHAs and EPAs in abundance and could be cultivated autotrophically for economic use [79]. This study, however, found only $T$. reginae to contain EPA isomers (11,14,17-eicosatrienoic acid, (Z,Z,Z)- and 11,14,17-eicosatrienoic acid, methyl esters) with an appreciable percentage abundance of $10.04 \pm 0.46$ and $10.62 \pm 0.10$ and DHA $(4,7,10,13,16,19$-docosahexaenoic acid, methyl ester) with a low $\%$ abundance of $0.77 \pm 0.07$. This indicates that, at optimal culturing conditions, $T$. reginae could be considered a sustainable omega- 3 oil source.

The quality of potential microalgae biodiesel was measured based on the biofuel properties, such as cetane number $(\mathrm{CN})$, iodine number (IV) and saponification number (SN). These parameters are strongly affected by the size of the carbon chain and the number of double bonds in the fatty acids of the feedstock oil. Cetane number is associated with long saturated fatty acid chains of carbon and enables the assessment of engine performance. A high $\mathrm{CN}$ guarantees good properties of ignition/combustion and minimises white smoke formation. Iodine number is a measure of a fatty material's gross unsaturation. Therefore, a lower degree of microalgal oil unsaturation results in a higher $\mathrm{CN}$ and a lower IV. Saponification number gives information on the average relative molecular mass of fatty acids [71]. It should be noted that these criteria have been commonly used to determine the quality of biodiesel, although they have not been sufficiently studied for algal oils to date to the best of our knowledge. The SN, IV and CN were determined from the FAME profile and presented in Table 3. The calculated critical indicators (IV and $\mathrm{CN}$ ) varied among the isolates. The study shows that all calculated IV values were within the European Standards (EN)14,214 maximum standard of 120 and $\mathrm{CN}$ values above the lowest acceptable limits of 51 and 47 for EN 14,214 and American society for testing and materials(ASTM) D6751-08, respectively [80]. When the sum of saturated fatty acids was greater than the unsaturated fatty acids, high $\mathrm{CN}$ values were achieved. Based on the above, the green microalgal isolates are potential excellent sources of quality biodiesel. However, despite these positive indicators which may make algal cultivation as a third-generation biofuel feedstock as magnificent option, application at an industrial scale is still lagging. This may be ascribed to negative attributes of the technology including the cost intensive process of algal mass culture with potential minimal biodiesel yield [81]

\section{Conclusion}

In this study, we isolated, identified and investigated two microalgal species, $C$. sorokiniana and $T$. reginae collected from Killarney Golf Course, Johannesburg-South Africa. Our work demonstrated that both isolates could be cultivated in artificial media for economic production of biomass, $\mathrm{CO}_{2}$ biosequestration and nutraceutical compounds and are potential sources for bioethanol and biodiesel production. The study further revealed that $T$. reginae remarkably outperformed $(p<0.05) C$. sorokiniana with regard to biomass production rate, total lipids and carbohydrate production, $\mathrm{CO}_{2}$ biosequestration rate and $\mathrm{C} / \mathrm{N}$ ratio. In addition, $T$. reginae contained a promising level of omega-3 oils. Chlorella sorokiniana was found to have a significant level of total protein. There was also a significant difference between the BBM and BG-11 media, making BBM a better medium for cultivating microalgae species for commercial value. From an economic point of view, the cost of preparing BBM is relatively lower than the preparation of the same quantity of BG-11 due to the chemical composition requirements. Hence, it makes economic sense to use BBM. Our study has shown that even though both isolates can be used as bioresources, T. reginae cultivated photoautotrophically in BBM has been proven to perform excellently as a bioresource and for $\mathrm{CO}_{2}$ fixation. It is also interesting to conclude that both isolates met both European and American quality biodiesel standards with exceptional IV and $\mathrm{CN}$ values.

Acknowledgements The authors would like to acknowledge the financial contributions from the Faculty of Science; Centre for Nanomaterials Science Research, University of Johannesburg, South Africa; and the National Research Foundation (TTK170405225933). EKA also acknowledges the financial contribution made by URC International Postgraduate Scholarships, University of Johannesburg, South Africa, toward this research work.

\section{Declarations}

Conflict of interest The authors declare no conflict of interest.

Open Access This article is licensed under a Creative Commons Attribution 4.0 International License, which permits use, sharing, adaptation, distribution and reproduction in any medium or format, as long as you give appropriate credit to the original author(s) and the source, provide a link to the Creative Commons licence, and indicate if changes were made. The images or other third party material in this article are included in the article's Creative Commons licence, unless indicated otherwise in a credit line to the material. If material is not included in the article's Creative Commons licence and your intended use is not 
permitted by statutory regulation or exceeds the permitted use, you will need to obtain permission directly from the copyright holder. To view a copy of this licence, visit http://creativecommons.org/licenses/by/4.0/.

\section{References}

1. Spolaore P, Joannis-Cassan C, Duran E, Isambert A (2006) Commercial applications of microalgae. J Biosci Bioeng 101:87-96

2. Randhir A, Laird DW, Maker G, Trengove R, Moheimani NR (2020) Microalgae: a potential sustainable commercial source of sterols. Algal Research 46:101772

3. Chew KW, Yap JY, Show PL, Suan NH, Juan JC, Ling TC, Lee D-J, Chang J-S (2017) Microalgae biorefinery: high value products perspectives. Biores Technol 229:53-62

4. Yun H-S, Kim Y-S, Yoon H-S (2020) Characterization of Chlorella sorokiniana and Chlorella vulgaris fatty acid components under a wide range of light intensity and growth temperature for their use as biological resources. Heliyon 6:e04447

5. Caporgno MP, Mathys A (2018) Trends in microalgae incorporation into innovative food products with potential health benefits. Front Nutr 5:58

6. Bellou S, Aggelis G (2013) Biochemical activities in Chlorella sp. and Nannochloropsis salina during lipid and sugar synthesis in a lab-scale open pond simulating reactor. Journal of Biotechnology 164:318-329

7. Dantas DMdM, Oliveira CYBd, Costa RMPB, Carneiro-da-Cunha MdG, Gálvez AO, Bezerra RdS (2019) Evaluation of antioxidant and antibacterial capacity of green microalgae Scenedesmus subspicatus. Food Science and Technology International 25:318-326

8. Cantley-Smith R (2021) Depositary of the Paris Agreement. Edward Elgar Publishing, In the Paris Agreement on Climate Change

9. Dlugokencky E, Tans $\mathrm{P}$ (2019) Trends in global $\mathrm{CO}_{2}$, National Oceanic \& Atmospheric Administration, Earth System Research Laboratory (NOAA/ESRL)

10. Lim YA, Chong MN, Foo SC, Ilankoon I (2021) Analysis of direct and indirect quantification methods of $\mathrm{CO}_{2}$ fixation via microalgae cultivation in photobioreactors: a critical review. Renewable and Sustainable Energy Reviews 137:110579

11. Mistry AN, Ganta U, Chakrabarty J, Dutta S (2019) A review on biological systems for $\mathrm{CO}_{2}$ sequestration: organisms and their pathways. Environ Prog Sustain Energy 38:127-136

12. Sydney EB, Sydney ACN, de Carvalho JC, Soccol CR (2019) Potential carbon fixation of industrially important microalgae. In Biofuels from algae. Elsevier 67-88

13. Oliveira CYB, Oliveira CDL, Prasad R, Ong HC, Araujo ES, Shabnam N, Gálvez AO (2021) A multidisciplinary review of Tetradesmus obliquus: a microalga suitable for large-scale biomass production and emerging environmental applications. Reviews in Aquaculture

14. Baker L (2016) Post-apartheid electricity policy and the emergence of South Africa's renewable energy sector. In The political economy of clean energy transitions. Oxford University Press, Oxford, pp 371-377

15. Entwisle T, Kraft G (1984) Survey of freshwater red algae (Rhodophyta) of south-eastern Australia. Mar Freshw Res 35:213-259

16. Desmet $P$ (2007) Namaqualand - a brief overview of the physical and floristic environment. J Arid Environ 70:570-587

17. Rippka R, Deruelles J, Waterbury JB, Herdman M, Stanier RY (1979) Generic assignments, strain histories and properties of pure cultures of cyanobacteria. Microbiology 111:1-61
18 Nichols HW, Bold HC (1965) Trichosarcina polymorpha gen. et sp. nov. Journal of Phycology 1:34-38

19. Dörrich AK, Wilde A (2015) Spot assays for viability analysis of cyanobacteria. Bio-protocol 5:e1574

20. Bashan Y, Lopez BR, Huss VA, Amavizca E, de-Bashan LE (2016) Chlorella sorokiniana (formerly C. vulgaris) UTEX 2714, a non-thermotolerant microalga useful for biotechnological applications and as a reference strain. J Appl Phycol 28:113-121

21. Hegewald E, Wolf M (2003) Phylogenetic relationships of Scenedesmus and Acutodesmus (Chlorophyta, Chlorophyceae) as inferred from 18S rDNA and ITS-2 sequence comparisons. Plant Syst Evol 241:185-191

22. Radha S, Fathima AA, Iyappan S, Ramya M (2013) Direct colony PCR for rapid identification of varied microalgae from freshwater environment. J Appl Phycol 25:609-613

23. Kumar S, Stecher G, Tamura K (2016) MEGA7: molecular evolutionary genetics analysis version 7.0 for bigger datasets. Molecular Biology and Evolution 33:1870-1874

24. Tamura K, Nei M (1993) Estimation of the number of nucleotide substitutions in the control region of mitochondrial DNA in humans and chimpanzees. Mol Biol Evol 10:512-526

25. Cataldo D, Maroon M, Schrader L, Youngs V (1975) Rapid colorimetric determination of nitrate in plant tissue by nitration of salicylic acid. Commun Soil Sci Plant Anal 6:71-80

26. Dubois M, Gilles KA, Hamilton JK, Rebers Pt, Smith F (1956) Colorimetric method for determination of sugars and related substances. Anal Chem 28:350-356

27. Axelsson M, Gentili F (2014) A single-step method for rapid extraction of total lipids from green microalgae. PLoS One 9:e89643

28. Lepage G, Roy CC (1984) Improved recovery of fatty acid through direct transesterification without prior extraction or purification. J Lipid Res 25:1391-1396

29. Van Wychen S, Laurens LML (2020) Total carbohydrate content determination of microalgal biomass by acid hydrolysis followed by spectrophotometry or liquid chromatography. In: Spilling K (ed) Biofuels from algae: methods and protocols. Springer New York, New York, pp 191-202

30. Zhou X, Xia L, Ge H, Zhang D, Hu C (2013) Feasibility of biodiesel production by microalgae Chlorella sp.(FACHB-1748) under outdoor conditions. Bioresour Technol 138:131-135

31. Laurens LM, Dempster TA, Jones HD, Wolfrum EJ, Van Wychen S, McAllister JS, Rencenberger M, Parchert KJ, Gloe LM (2012) Algal biomass constituent analysis: method uncertainties and investigation of the underlying measuring chemistries. Anal Chem 84:1879-1887

32. López CVG, García MdCC, Fernández FGA, Bustos CS, Chisti Y, Sevilla JMF (2010) Protein measurements of microalgal and cyanobacterial biomass. Bioresour Technol 101:7587-7591

33. Mota MFS, Souza MF, Bon EP, Rodrigues MA, Freitas SP (2018) Colorimetric protein determination in microalgae (Chlorophyta): association of milling and SDS treatment for total protein extraction. J Phycol 54:577-580

34. Chia SR, Chew KW, MohdZaid HF, Chu D-T, Tao Y, Show PL (2019) Microalgal protein extraction from Chlorella vulgaris FSP-E using triphasic partitioning technique with sonication. Frontiers in Bioengineering and Biotechnology 7:396

35. Mayo AW (1997) Effects of temperature and $\mathrm{pH}$ on the kinetic growth of unialga Chlorella vulgaris cultures containing bacteria. Water Environ Res 69:64-72

36. Lee K, Eisterhold ML, Rindi F, Palanisami S, Nam PK (2014) Isolation and screening of microalgae from natural habitats in the midwestern United States of America for biomass and biodiesel sources. Journal of Natural Science, Biology, and Medicine 5:333 
37. Purkayastha J, Bora A, Gogoi HK, Singh L (2017) Growth of high oil yielding green alga Chlorella ellipsoidea in diverse autotrophic media, effect on its constituents. Algal Res 21:81-88

38. Abd El Fatah HM, El-Baghdady KZ, Zakaria AE, Sadek HN (2020) Improved lipid productivity of Chlamydomonas globosa and Oscillatoria pseudogeminata as a biodiesel feedstock in artificial media and wastewater. Biocatalysis and Agricultural Biotechnology 25:101588

39. Gumbi S, Majeke B, Olaniran A, Mutanda T (2017) Isolation, identification and high-throughput screening of neutral lipid producing indigenous microalgae from South African aquatic habitats. Appl Biochem Biotechnol 182:382-399

40. Malibari R, Sayegh F, Elazzazy AM, Baeshen MN, Dourou M, Aggelis G (2018) Reuse of shrimp farm wastewater as growth medium for marine microalgae isolated from Red Sea-Jeddah. J Clean Prod 198:160-169

41. Hindák F, Hindáková A (2008) Morphology and taxonomy of some rare chlorococcalean algae (Chlorophyta). Biologia 63:781-790

42. Mutanda T, Ramesh D, Karthikeyan S, Kumari S, Anandraj A, Bux F (2011) Bioprospecting for hyper-lipid producing microalgal strains for sustainable biofuel production. Biores Technol 102:57-70

43. Sekatresna W, Dharma A, Zein R, Chaidir Z (2015) Isolation and characterization of microalgae isolated from palm oil mill effluent (POME) for biodiesel feed stocks with $\beta$-carotene as co-product. J Chem Pharm Res 7:222-231

44. Ferro L, Gentili FG, Funk C (2018) Isolation and characterization of microalgal strains for biomass production and wastewater reclamation in Northern Sweden. Algal Res 32:44-53

45. Yanuhar U, Caesar NR, Musa M (2019) Identification of local isolate of microalgae Chlorella vulgaris using ribulose-1, 5-bisphosphate carboxylase/oxygenase large subunit ( $\mathrm{rbcL}$ ) gene, in IOP Conference Series: Materials Science and Engineering, IOP Publishing, pp. 022038

46. Peredo EL, Cardon ZG (2020) Shared up-regulation and contrasting down-regulation of gene expression distinguish desiccation-tolerant from intolerant green algae. Proc Natl Acad Sci 117:17438-17445

47. Naidoo RK, Simpson ZF, Oosthuizen JR, Bauer FF (2019) Nutrient exchange of carbon and nitrogen promotes the formation of stable mutualisms between chlorella sorokiniana and saccharomyces cerevisiae under engineered synthetic growth conditions. Front Microbiol 10:1-16

48. Tsarenko P, Petlevanny O (2001) Addition to the diversity of algae of Ukraine. Algologia, Supplement 1-130

49. Hegewald E, Bock C, Krienitz L (2013) A phylogenetic study on Scenedesmaceae with the description of a new species of Pectinodesmus and the new genera Verrucodesmus and Chodatodesmus (Chlorophyta, Chlorophyceae). Fottea 13:14

50. Wynne MJ, Hallan JK (2015) Reinstatement of Tetradesmus GM Smith (Sphaeropleales, Chlorophyta). Feddes Repertorium 126:83-86

51. Smith GM (1913) Tetradesmus, a new four-celled coenobic alga. Bull Torrey Bot Club 40:75-87

52. Goh BHH, Ong HC, Cheah MY, Chen W-H, Yu KL, Mahlia TMI (2019) Sustainability of direct biodiesel synthesis from microalgae biomass: a critical review. Renew Sustain Energy Rev 107:59-74

53. Brindhadevi K, Mathimani T, Rene ER, Shanmugam S, Chi NTL, Pugazhendhi A (2021) Impact of cultivation conditions on the biomass and lipid in microalgae with an emphasis on biodiesel. Fuel 284:119058

54. Roopnarain A, Gray VM, Sym S (2014) Influence of nitrogen stress on Isochrysis galbana strain U 4, a candidate for biodiesel production. Phycol Res 62:237-249
55. Lugo LA, Thorarinsdottir RI, Bjornsson S, Palsson OP, Skulason H, Johannsson S, Brynjolfsson S (2020) Remediation of aquaculture wastewater using the microalga Chlorella sorokiniana. Water 12:3144

56 Gour RS, Chawla A, Singh H, Chauhan RS, Kant A (2016) Characterization and screening of native Scenedesmus sp. isolates suitable for biofuel feedstock. PloS One 11:e0155321

57. Apandi N, Mohamed RMSR, Al-Gheethi A, Gani P, Ibrahim A, Kassim AHM (2019) Scenedesmus biomass productivity and nutrient removal from wet market wastewater, A bio-kinetic study. Waste and Biomass Valorization 10:2783-2800

58. Li T, Zheng Y, Yu L, Chen S (2013) High productivity cultivation of a heat-resistant microalga Chlorella sorokiniana for biofuel production. Biores Technol 131:60-67

59. Thanh PD (2019) Biomass and lipid productivity of scenedesmus deserticola under heterotrophic cultivation. AGU International Journal of Sciences 7:39-48

60. Xin L, Hong-Ying H, Ke G, Ying-Xue S (2010) Effects of different nitrogen and phosphorus concentrations on the growth, nutrient uptake, and lipid accumulation of a freshwater microalga Scenedesmus sp. Biores Technol 101:5494-5500

61. Scherholz ML, Curtis WR (2013) Achieving pH control in microalgal cultures through fed-batch addition of stoichiometricallybalanced growth media. BMC Biotechnol 13:1-17

62. Oliveira CYB, D'Alessandro EB, Antoniosi Filho NR, Lopes RG, Derner RB (2021) Synergistic effect of growth conditions and organic carbon sources for improving biomass production and biodiesel quality by the microalga Choricystis minor var. minor. Science of the Total Environment 759:143476

63. Taziki M, Ahmadzadeh H, Murry MA, Lyon SR (2015) Nitrate and nitrite removal from wastewater using algae. Curr Biotechnol 4:426-440

64. Jeanfils J, Canisius M, Burlion N (1993) Effect of high nitrate concentrations on growth and nitrate uptake by free-living and immobilized Chlorella vulgaris cells. J Appl Phycol 5:369-374

65. Wang B, Lan CQ (2011) Biomass production and nitrogen and phosphorus removal by the green alga Neochloris oleoabundans in simulated wastewater and secondary municipal wastewater effluent. Biores Technol 102:5639-5644

66. Ogbonna JC, Yoshizawa H, Tanaka H (2000) Treatment of high strength organic wastewater by a mixed culture of photosynthetic microorganisms. J Appl Phycol 12:277-284

67. Wang J, Curtis WR (2016) Proton stoichiometric imbalance during algae photosynthetic growth on various nitrogen sources: toward metabolic pH control. J Appl Phycol 28:43-52

68. Ahmad Latiffi NA, Radin Mohamed RMS, Apandi NM, Tajuddin RM (2017) Experimental assessment on effects of growth rates microalgae Scenedesmus sp. in different conditions of $\mathrm{pH}$, temperature, light intensity and photoperiod, in Key Engineering Materials, Trans Tech Publ, pp. 546-551

69. Qiu R, Gao S, Lopez PA, Ogden KL (2017) Effects of pH on cell growth, lipid production and $\mathrm{CO} 2$ addition of microalgae Chlorella sorokiniana. Algal Res 28:192-199

70. Barten RJ, Wijffels RH, Barbosa MJ (2020) Bioprospecting and characterization of temperature tolerant microalgae from Bonaire. Algal Research 50:102008

71. Jazzar S, Berrejeb N, Messaoud C, Marzouki MN, Smaali I (2016) Growth parameters, photosynthetic performance, and biochemical characterization of newly isolated green microalgae in response to culture condition variations. Appl Biochem Biotechnol 179:1290-1308

72. Gong Y, Jiang M (2011) Biodiesel production with microalgae as feedstock: from strains to biodiesel. Biotech Lett 33:1269-1284

73. Sharma AK, Sahoo PK, Singhal S, Patel A (2016) Impact of various media and organic carbon sources on biofuel production potential from Chlorella spp. 3 Biotech 6:1-12 
74. Goncalves EC, Wilkie AC, Kirst M, Rathinasabapathi B (2016) Metabolic regulation of triacylglycerol accumulation in the green algae: identification of potential targets for engineering to improve oil yield. Plant Biotechnol J 14:1649-1660

75. Li C, Yu Y, Zhang D, Liu J, Ren N, Feng Y (2016) Combined effects of carbon, phosphorus and nitrogen on lipid accumulation of Chlorella vulgaris in mixotrophic culture. J Chem Technol Biotechnol 91:680-684

76. Ananthi V, Pugazhendhi A, Arun A (2020) Efficacy of chemical factors on production and extraction of biodiesel by microalgae. International Journal of Energy Research

77. Vuppaladadiyam AK, Prinsen P, Raheem A, Luque R, Zhao M (2018) Microalgae cultivation and metabolites production: a comprehensive review. Biofuels, Bioprod Biorefin 12:304-324

78. Bellou S, Baeshen MN, Elazzazy AM, Aggeli D, Sayegh F, Aggelis G (2014) Microalgal lipids biochemistry and biotechnological perspectives. Biotechnol Adv 32:1476-1493
79. Li X, Liu J, Chen G, Zhang J, Wang C, Liu B (2019) Extraction and purification of eicosapentaenoic acid and docosahexaenoic acid from microalgae: a critical review. Algal Research 43:101619

80. Hoekman SK, Broch A, Robbins C, Ceniceros E, Natarajan M (2012) Review of biodiesel composition, properties, and specifications. Renew Sustain Energy Rev 16:143-169

81. Khan MI, Shin JH, Kim JD (2018) The promising future of microalgae: current status, challenges, and optimization of a sustainable and renewable industry for biofuels, feed, and other products. Microb Cell Fact 17:1-21

Publisher's note Springer Nature remains neutral with regard to jurisdictional claims in published maps and institutional affiliations. 